Review Article

\title{
Diabetes Mellitus and Liver Surgery: The Effect of Diabetes on Oxidative Stress and Inflammation
}

\author{
Mariana Mendes-Braz $(\mathbb{D})$ and Joilson O. Martins \\ Laboratory of Immunoendocrinology, Department of Clinical and Toxicological Analyses, School of Pharmaceutical Sciences of \\ University Sao Paulo (FCF/USP), São Paulo, SP, Brazil
}

Correspondence should be addressed to Mariana Mendes-Braz; marianamb@usp.br and Joilson O. Martins; martinsj@usp.br Received 22 October 2017; Revised 2 April 2018; Accepted 11 April 2018; Published 8 May 2018

Academic Editor: Fumio Tsuji

Copyright (c) 2018 Mariana Mendes-Braz and Joilson O. Martins. This is an open access article distributed under the Creative Commons Attribution License, which permits unrestricted use, distribution, and reproduction in any medium, provided the original work is properly cited.

Diabetes mellitus $(\mathrm{DM})$ is a metabolic disorder characterized by hyperglycaemia and high morbidity worldwide. The detrimental effects of hyperglycaemia include an increase in the oxidative stress (OS) response and an enhanced inflammatory response. DM compromises the ability of the liver to regenerate and is particularly associated with poor prognosis after ischaemia-reperfusion (I/R) injury. Considering the growing need for knowledge of the impact of DM on the liver following a surgical procedure, this review aims to present recent publications addressing the effects of DM (hyperglycaemia) on OS and the inflammatory process, which play an essential role in I/R injury and impaired hepatic regeneration after liver surgery.

\section{Introduction}

To extirpate a macroscopic lesion or accomplish a transplant, the blood flow to the liver must be interrupted to avoid the haemorrhagic process. Despite the safety of surgical procedures that involve the interruption of blood flow to the liver (ischaemia), this interruption contributes to tissue damage, which is potentiated by the restoration of blood flow (reperfusion). This phenomenon, known as ischaemia-reperfusion $(\mathrm{I} / \mathrm{R})$ injury $[1,2]$, is associated with inflammation and oxidative stress (OS) [3].

Diabetes mellitus (DM) is a metabolic disorder resulting from deficient insulin secretion and/or insulin action, leading to hyperglycaemia (high blood glucose) [4], which causes oxidative damage and activates inflammatory signalling cascades [5], in addition to acting as a damaging agent exacerbating the pathological conditions of DM $[6,7]$. Considering the growing need for knowledge about the impact of DM on livers undergoing a surgical procedure, the present review aims to present recent data concerning the effects of DM (hyperglycaemia) on OS and the inflammatory process.

\section{Oxidative Stress}

Under normal conditions, the hepatic production of prooxidants, such as reactive oxygen species (ROS), is counterbalanced by antioxidants. An imbalance in favour of prooxidants corresponds to OS, and the direct action of ROS on cell viability and function is directly related to the occurrence of several pathological processes in the liver [8]. OS plays an essential role in liver surgery [9], and diabetes is generally followed by increased free radical production [10-13] or reduced antioxidant protection $[14,15]$. To better understand the effect of DM (hyperglycaemia) on OS, this section will describe research findings that help clarify the association of DM with liver surgery.

2.1. Diabetes Mellitus and Ischaemia-Reperfusion Injury. Hydrogen peroxide $\left(\mathrm{H}_{2} \mathrm{O}_{2}\right)$, a mild and relatively stable oxidant that is formed in tissues exposed to $I / R$, has been considered a representative ROS for evaluating the response of cells to OS [16]. Although $\mathrm{H}_{2} \mathrm{O}_{2}$ is not a free radical, its accumulation may promote the formation of more toxic species, such as hydroxyl radicals $(\bullet \mathrm{OH})$, through 
the Fenton reaction [17]. $\mathrm{H}_{2} \mathrm{O}_{2}$ can cause permanent growth arrest [18, 19] and apoptosis [20-22] in a number of cell types. Nuclear (8-hydroxy-2' -deoxyguanosine) 8-OHdG formation indicates the presence of OS in nuclei [23]. The liver is a major organ affected by ROS [24] and is susceptible to the effects of OS induced by hyperglycaemia, causing liver injury [25-27]. Zhang et al. [28] found that serum $\mathrm{H}_{2} \mathrm{O}_{2}$ and nuclear 8-OHdG levels were higher in streptozotocin(STZ-) induced diabetic rats subjected to I/R compared with the diabetic control group. ROS induce lipid peroxidation, which causes membrane injury, in addition to changes in ion permeability, enzyme activity, and, ultimately, cell death. Malondialdehyde (MDA), an indicator of oxidative injury produced via lipid peroxidation [29], is significantly enhanced in STZ-induced diabetic rats compared with normal rats and increases after I/R [28, 30] (Figure 1).

Apoptosis and necrosis can occur after I/R. An intense injury leads to initial necrotic killing, whereas late apoptosis may follow moderate injury [31]. STZ-induced diabetic rats exposed to an ischaemic period present significantly increased hepatocyte degeneration, sinusoidal dilatation, nuclear pyknosis, and cellular necrosis compared with the diabetes sham group [30]. In spite of this experimental difference, Behrends et al. [32] reported that necrosis is the preferential form of cell death in the liver of hyperglycemic rats (due to intraperitoneal injection of $25 \%$ glucose) subjected to I/R. The authors [32] noted that this increased injury may be associated with the inhibition of heat shock proteins (HSPs), which is only possible through the association of hyperglycaemia and I/R. The hyperglycaemia alone was not enough for HSP32 and HSP70 downregulation. HSPs are considered to be an indispensable protective agent against $\mathrm{I} / \mathrm{R}$ injury because they are able to protect the liver from OS [33] (Figure 1).

Cell adaptation to OS is a consequence of the upregulation of distinct cytoprotective genes responsible for buffering the antioxidant capacity of the cell [34]. Under physiological conditions, an antioxidant defence system protects the body against the harmful effects of free radicals [35]. Diabetic livers are vulnerable to attack by oxygen free radicals because they present overall antioxidant depression [14]. Release of ROS and the concurrent consumption of endogenous antioxidants and cell death (apoptosis or necrosis) occur during hepatic I/ $\mathrm{R}$ [36]. After I/R, nuclear factor (erythroid-derived 2)-like-2 factor (Nrf2), a transcription factor that mediates the expression of many endogenous antioxidants plays an important role in opposing hepatic injury [37]. Zhang et al. [28] reported that, after $\mathrm{I} / \mathrm{R}$ injury, hepatocytes pretreated with high glucose $(25 \mathrm{mM})$ exhibited a reduction in the antioxidative ability of the Nrf2 pathway and a substantial increase in nuclear factor kappa $\mathrm{B}(\mathrm{NF}-\kappa \mathrm{B})$ translocation; however, NF- $\kappa \mathrm{B}$ activation was already enhanced in these hepatocytes before I/R injury. Interestingly, NF- $\kappa \mathrm{B}$, a transcription factor that reacts to redox signals, may directly repress Nrf2 signalling at the transcriptional level [38, 39]. Zhang et al. [28] postulated that high glucose-induced ROS overproduction could initiate the inhibitory interaction between $\mathrm{NF}-\kappa \mathrm{B}$ and $\mathrm{Nrf} 2$ (Figure 1). However, the precise mechanisms involved in the NF- $\kappa \mathrm{B}$ and Nrf2 interaction under hyperglycaemic conditions require further elucidation.

Under normal conditions, the body presents a potent antioxidant system that is responsible for protecting it from the harmful effects of ROS [40]. Endogenous antioxidant enzymes attenuate I/R injury in the liver [36]. In both type 1 and type 2 DM, antioxidant defence enzymes are deficient, and there is an increase in oxidative damage [41]. High levels of ROS such as superoxide $\left(\mathrm{O}_{2}{ }^{-}\right)$are found in diabetes and especially during I/R injury [42]. Cem Sezen et al. [30] showed that there is an increase in glutathione s-transferase (GST) in STZ-induced diabetic mice post-I/R with respect to diabetic rats. Between these two groups, there was no difference in the level of superoxide dismutase (SOD); however, compared with the sham group (nondiabetic), there was a marked decrease in SOD levels. The orchestrated actions of several antioxidants in mammalian cells are essential for efficiently detoxifying free radicals. Therefore, any impairment in this pathway will influence the activities of other enzymes $[43,44]$. Reduction in the activity of SOD will result in an increased level of $\mathrm{O}_{2}{ }^{-}$[45]. GST is known to be an early and sensitive marker of liver injury and has been shown to increase after liver ischaemia/reperfusion [46]. This increased activity of GST could be explained as a compensatory mechanism to protect the organism against injury [47]. These findings are not only in accord with the diverse signalling pathways related to postoperative liver injury associated with DM (Figure 1) but also indicate the importance of the determination of increased ROS production and its characteristic consequences in postischaemic tissues, permitting the identification of interventions that stimulates ROS detoxification, and consequently protect against reperfusion injury [16], mainly in a diabetic context (Figure 1).

2.2. Diabetes Mellitus and Liver Regeneration. An increase in lipid peroxidation was found to be important for a normal proliferative process to occur in the liver remnant after partial hepatectomy $(\mathrm{PH})[48,49]$. Francés et al. [50] reported that OS is increased by hyperglycaemia and is juxtaposed with the effect of PH in STZ-induced diabetic rats. Postoperative recovery depends on the regenerative capacity of the residual liver. The liver presents altered intracellular signalling pathways in type 1 DM specimens [51-53] and a consequent deficient regenerative response [54]. STZ-induced diabetic rats were found to present an increase in $\bullet \mathrm{OH}$ production, which could result in DNA damage $[55,56]$ (Figure 1). Hyperglycaemia in STZ-induced diabetic rats leads to an increase in hepatic ROS production and is further enhanced after PH. STZ-induced diabetic rats subjected to $\mathrm{PH}$ present a decrease in the level of proliferating cell nuclear antigen (PCNA) and a significant decrease in cyclin D1 levels, suggesting that few hepatocytes are capable of entering the cell cycle [50].

Hyperglycaemia enhances $\bullet \mathrm{OH}$ radical levels and consequent Bax protein induction. After PH, STZ-induced diabetic rats were found to present an increase in proapoptotic events (Bax/Bcl-xL ratio, caspase- 3 activity, and cytosolic cytochrome c) compared with the diabetic group 


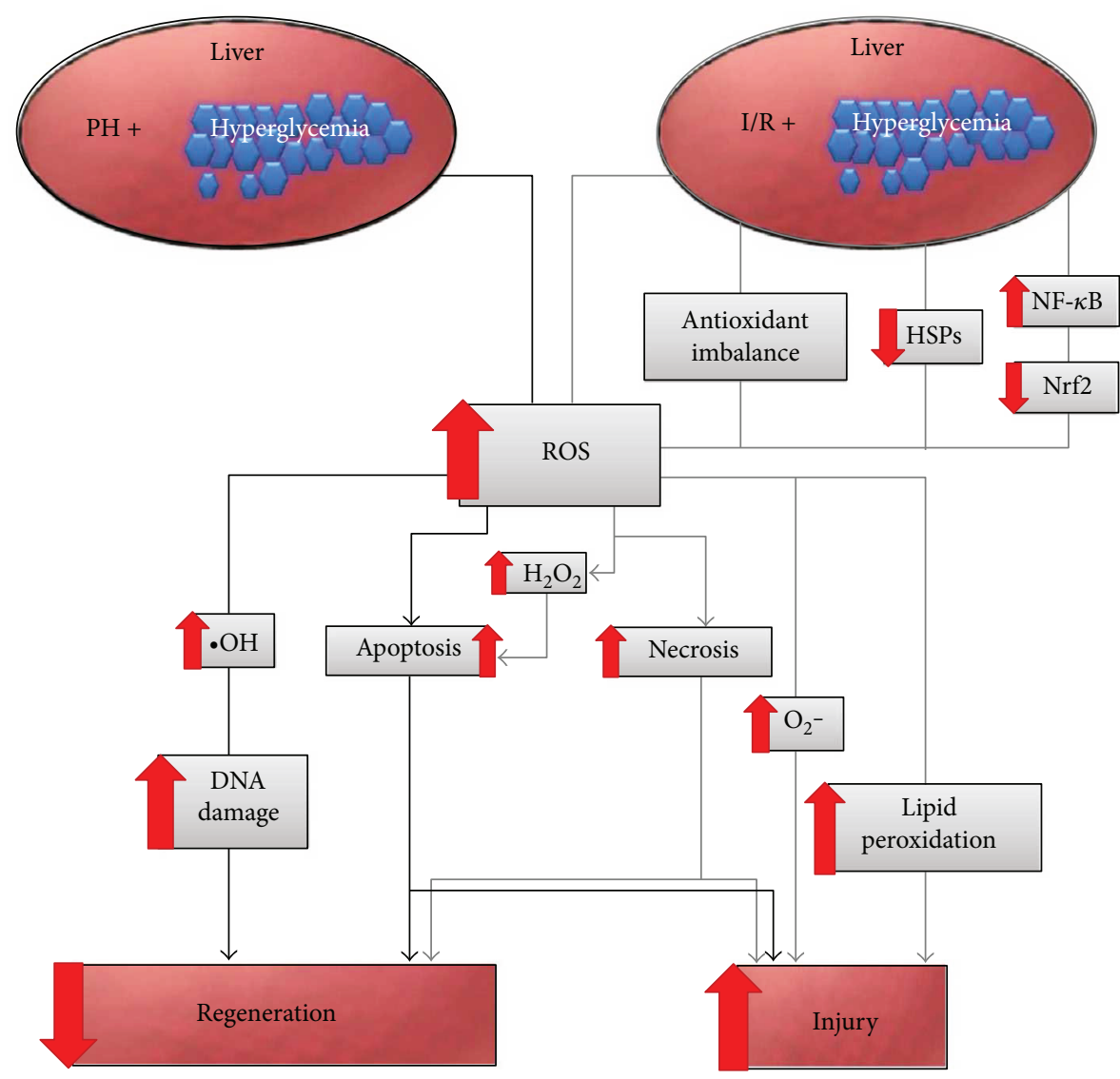

FIgURE 1: Mechanisms of OS in the promotion of liver damage and impaired regeneration after liver surgery in association with DM. The illustration shows the molecular events subsequent to the surgical procedure performed on the diabetic liver, which leads to a significant increase of ROS, inducing liver injury and regeneration. $\mathrm{PH}$, partial hepatectomy; I/R, ischaemia-reperfusion; $\mathrm{O}_{2}^{-}$, superoxide anion; $\mathrm{HSP}_{\text {, }}$ heat shock protein; NF- $\kappa$ B, nuclear factor kappa B; Nrf2, nuclear factor (erythroid-derived 2)-like-2 factor; $\mathrm{H}_{2} \mathrm{O}_{2}$, hydrogen peroxide; $\bullet \mathrm{OH}$, hydroxyl radical.

[50] (Figure 1). The diversity of the results of different studies $[30,32,50,55]$ shows that the association of hyperglycaemia with different surgical modalities leads to differences in the type of cell death. It is imperative to identify the effects of diabetes on cell death after more complex surgical procedures leading to pronounced liver injury, such as liver transplantation and $\mathrm{PH}$ under $\mathrm{I} / \mathrm{R}$.

\section{Inflammation}

Hepatic inflammation is a complex process that is initiated in response to stressful conditions to protect hepatocytes from injury. However, overly intense inflammatory responses are followed by massive hepatocyte loss, causing irreversible parenchymal damage [57]. Liver damage is a serious complication in DM [58]. Surgical procedures induce acute inflammation, which is characterized by the production and release of various chemical mediators, including cytokines [59]. In the next section, the effects of DM (hyperglycaemia) on the hepatic inflammatory process after a surgical procedure will be discussed.

3.1. Diabetes Mellitus and Ischaemia-Reperfusion Injury. The pathophysiology of hepatic I/R injury is not only related to the direct cell impairment caused by ischaemic insult but also results from the restoration of blood flow, which triggers the proinflammatory environment. Diabetic patients present a variety of deficient immune cell functions [60, 61], and diabetic animals exhibit abnormalities in the course of the inflammatory response, with a consequent decrease in the number of leukocytes in inflammatory injuries $[62,63]$, the airway inflammatory response to antigen challenge $[64,65]$, mast cell degranulation $[66,67]$, superoxide generation, and tumour necrosis factor- (TNF-) $\alpha$ release by leukocytes upon exposure to lipopolysaccharides [68]. The difficulty in arriving at any consistent conclusion is due to the conflicting views regarding the impact of hyperglycaemia on inflammatory responses between different reports. Since clinical observations have revealed that the association between hyperglycaemia and immune alterations could increase the risk for rejection in transplantation, the substantial inflammatory response associated with $\mathrm{I} / \mathrm{R}$ injury appears to be mediated by an exaggerated adhesion of leukocytes to the endothelium $[69,70]$.

The hyperinflammatory phenotype associated with DM may induce a liver immune response against I/R, which could favour an increase in parenchymal damage [71]. In the initial phase of liver injury, different events trigger a complex 
inflammatory pathway that leads to hepatic accumulation of neutrophils [72]. Through the release of oxidants and proteases, hepatocytes are directly damaged by recruited neutrophils, which are involved in by the later phase of liver injury induced by I/R [73]. In the livers of hyperglycaemic rats subjected to $I / R$, Behrends et al. [32] observed an increase in neutrophil infiltration (Figure 2). Interestingly, in association with microvascular dysfunction in response to $\mathrm{I} / \mathrm{R}$, neutrophil infiltration is exacerbated in DM, suggesting that DM predisposes tissues to the detrimental consequences of $\mathrm{I} / \mathrm{R}$, which is a deleterious process that is broadly mediated by neutrophils [69].

The immune system responds to liver injury and/or stress through the activation of resident Kupffer cells (KCs), which release proinflammatory cytokines and other factors [74]. A prominent feature of liver injury is an increase in the hepatic macrophage population [75]. Considering cellular and molecular mechanisms, Yue et al. [71] showed that I/R stimulates the release of advanced glycation end products (AGE) into the blood of STZ-induced diabetic mice and that KCs express higher levels of the receptor for AGE (RAGE). The authors [71] proposed that RAGE may exhibit different functions in a cell type-specific manner. In normal mice, RAGE regulates hepatocyte proliferation during the restoration phase of I/R, whereas in diabetic mice, RAGE activates the hepatic immune system. These findings support the hypothesis that DM may be a factor involved in the course and evolution of I/R injury after liver surgery.

Activated KCs respond with a classic inflammatory reaction and consequent production of proinflammatory cytokines [76-80]. At 6 hours after reperfusion, TNF- $\alpha$ and interleukin- (IL-) 6 levels were found to be increased, while the IL-10 level was decreased on STZ-induced diabetic mice [71, 81] (Figure 2), whereas in control mice, KCs not only presented increases in TNF- $\alpha$ and IL- 6 but also an increase in IL-10 [81]. The activation of IL-10 during a proinflammatory response may represent an important agent in the regulation of intensive inflammation in a stressful situation. These findings not only illustrate the defensive role of KCs during liver I/R injury in opposing the hyperinflammatory response through IL-10 expression but also show that hyperglycemic mice subjected to $I / R$ present a significant decrease in IL-10 secretion, by KCs, which is related to uncontrolled inflammation and robust hepatic I/R injury [81].

Several studies suggest that endoplasmic reticulum stress and CHOP signalling could be upregulated by RAGE signalling [82-85]. After 6 hours of reperfusion, C/EBP homologous protein (CHOP) levels in KCs were found to be stimulated by I/R and were further increased in STZinduced hyperglycemic mice. In hyperglycemic KCs, overactivation of CHOP is related to the inhibition of STAT3 and STAT6 activation. The signal transducers and activators of transcription (STATs) regulate the polarization of macrophages [86], and diabetic mice present M2 KC phenotype inhibition, which results in increased inflammation under hepatic I/R when the rodents exhibit interruption of IL-10secreting M2 differentiation [81]. Additionally, mice that are only subjected to ischaemia show development of M2- type macrophages, which protect livers from I/R via an IL10-dependent mechanism [87] (Figure 2).

In the pathogenesis of DM, activated innate immunity and inflammation are important factors. Type $2 \mathrm{DM}$ involves inflammatory elements $[88,89]$, and type $1 \mathrm{DM}$ is regarded as an inflammatory process [90]. NF- $\kappa \mathrm{B}$ is a transcription factor that is activated in the diabetic liver [91-93] and is involved in events that lead to inflammation [94]. NF- $\kappa$ B regulates the expression of many inflammatory cytokines, including monocyte chemotactic protein- (MCP-) 1, IL-6, and TNF- $\alpha[95,96]$, which are proinflammatory cytokines that may activate neutrophils and KCs [97]. Zhang et al. [28] showed that after 6 hours of reperfusion, the levels of these hepatic cytokines were significantly higher in STZinduced diabetic rats and further increased after the ischaemic period. These results suggested that NF- $\kappa \mathrm{B}$ might also be involved in hepatic $I / R$ in diabetic rats (Figure 2 ). The investigation of NF- $\kappa \mathrm{B}$ activation in diabetic livers subjected to surgical procedures should be extended to cell death. Between NF- $\kappa \mathrm{B}$ and TNF- $\alpha$, there is an autocrinereinforcing loop $[98,99]$. The hepatic increase of TNF- $\alpha$ in STZ-induced diabetic rats leads to pronounced upregulation of the NF- $\kappa \mathrm{B}$ pathway [100], and NF- $\kappa \mathrm{B}$ activation induced by hyperglycaemia mediates cell apoptosis [101, 102].

Several inflammatory cytokines (e.g., TNF- $\alpha$ ) and arachidonic acid metabolites (prostaglandins and thromboxanes) are involved in liver injury induced by I/R. Cyclooxygenase (COX) regulates the production of prostanoids [103], and inhibition of COX-2 protects against hepatic I/R injury [104, 105], which suggests that COX-2 is associated with organ injury and contributes to hepatic microvascular and hepatocellular injuries through TNF- $\alpha$ production [103]. Hepatocyte apoptosis stimulated by TNF is associated with c-Jun N-terminal kinase (JNK) activation [106]. Conversely, Francés et al. [107] showed that STZ-induced diabetic COX-2 transgenic mice presented a substantial decrease in apoptosis and that COX-2 overexpression could prevent the increase in JNK activity stimulated by high glucose. The authors [107] also showed that the increased expression of COX-2 in diabetic COX-2 transgenic mice induces an increase of phosphoinositide 3-kinase (PI3K) activity compared with diabetic wild-type mice, in addition to favouring the activation of Akt and producing an antiapoptotic signal [107]. These studies call attention not only to the contradictory roles of diabetes in orchestrating hepatocyte activity but also to the necessity of clearly understanding the consequences of diabetes for cell death after liver surgery (Figure 2).

3.2. Diabetes Mellitus and Liver Regeneration. In a model of type $2 \mathrm{DM}$ (ob/ob murine), liver regeneration was found to be impaired after $70 \% \mathrm{PH}$, which resulted in $90 \%$ mortality [108]. The regenerative ability of the liver is compromised in type 1 diabetic rats subjected to $\mathrm{PH}[51,52,109]$. In patients subjected to a major hepatectomy, DM tends to induce postoperative liver failure [110]. Considering the mechanisms of regeneration failure, diabetic and obese KK-Ay mice exhibit abnormal responses after $\mathrm{PH}$ [111] and present excessive induction of hepatic TNF- $\alpha$ 


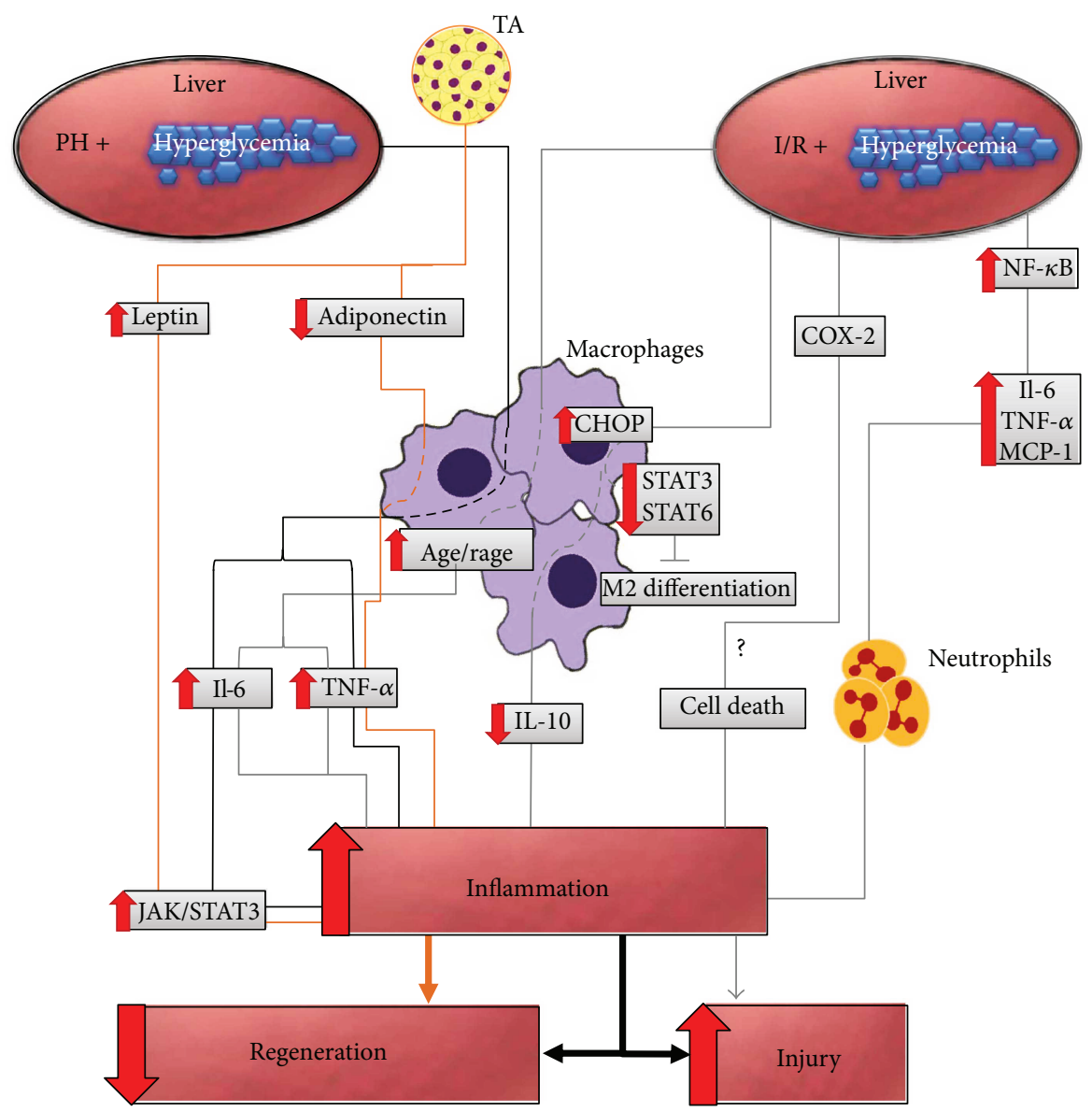

FIGURE 2: Inflammatory mechanisms underlying the promotion of liver damage and impaired regeneration after liver surgery in association with DM. The illustration shows the molecular events subsequent to the surgical procedure performed on the diabetic liver, inducing the participation of inflammatory cells and consequent cytokine production, leading to liver injury and regeneration. TA, adipose tissue; AGE, advanced glycation end products; RAGE, receptor for AGE; IL-6, interleukin-6; IL-10, interleukin-10; TNF- $\alpha$, tumour necrosis factor- $\alpha$; MCP-1, monocyte chemoattractant protein-1; JAK, Janus kinase; STAT3, signal transducer and activator of transcription 3; CHOP, C/EBP homologous protein; NF- $\kappa$ B, nuclear factor kappa B; COX-2, cyclooxygenase-2; $\mathrm{PH}$, partial hepatectomy; I/R, ischaemia-reperfusion.

expression. Although TNF- $\alpha$ is important for the initiation of normal hepatic regeneration $[112,113]$, excess induction of TNF- $\alpha$ in KCs might interfere with the regenerative process [111] (Figure 2).

Adipose tissue is involved in a number of biological functions, including inflammation, and acts as an endocrine organ through the secretion of several biologically active substances known as "adipokines" [114]. During liver regeneration, systemic adipose stores are required as a source of various adipokines, such as adiponectin, which is an essential signal for liver regeneration [115]. Aoyama et al. [111] showed that the serum adiponectin level was significantly reduced in KK-Ay mice before $\mathrm{PH}$ and tended to decrease gradually after $\mathrm{PH}$. Adiponectin has been found to inhibit the lipopolysaccharide-dependent activation of macrophages $[116,117]$. The significant hypoadiponectinemia presented by KK-Ay mice could be related to the fact that the KCs of these animals are more susceptible to certain stimuli; moreover, the hypoadiponectinemia caused by this susceptibility could be further associated with the increased production of TNF- $\alpha$ by KCs, which may interfere with regenerative responses [111] (Figure 2). Adiponectin mediates antiinflammatory effects. However, since this role for adiponectin was found to depend on surgical conditions, the function of adiponectin in the inflammatory process is a controversial issue [118]. While injurious effects of adiponectin on steatotic livers subjected to warm ischaemia (60 minutes) were identified by Massip-Salcedo et al. [119], the beneficial (anti-inflammatory) effects of adiponectin on small fatty grafts subjected to cold ischaemia (40 minutes) were observed by Man et al. [120]. Although these findings were obtained in steatotic livers, these results suggest opportunities for investigation of the effect of adiponectin on diabetic livers subjected to different surgical procedures.

IL- 6 is a protein synthesized by fibroblasts, monocytes, macrophages, $\mathrm{T}$ cells, and endothelial cells [121] that plays an important role in hepatic regeneration [122, 123]. Adipokines exhibit proinflammatory or anti-inflammatory activities [124], and leptin presents proinflammatory properties $[125,126]$. IL-6 and leptin function in the Janus kinase(JAK-) STAT3 signalling pathway [111]. KK-Ay mice present a substantial increase in the levels of IL- 6 and leptin 
following PH [111]. Despite the important role of the JAKSTAT pathway in hepatic protection against different hepatic injuries $[127,128]$ and the evidence that IL-6, leptin, and the JAK-STAT signalling pathway are essential to liver regeneration [129-132], Aoyama et al. [111] showed that the role of the JAK-STAT pathway in hepatic regeneration seems to be complex and dependent on the intensity of the stimulus, showing that hyperphosphorylation of STAT3 favours poor hepatic regeneration as a result of direct downregulation of cyclin D1 expression (Figure 2).

\section{Diabetes Mellitus in Clinical Situations}

There is an absence of clinical studies elucidating signalling pathways related to liver damage and impaired regeneration in diabetic patients undergoing surgery. Nevertheless, it is indispensable to discuss and generate hypotheses about this issue, which is quite controversial because some studies have shown that DM patients present a poorer prognosis after hepatic surgery in comparison with non-DM patients, whereas others show no difference [133].

Focusing on the issues addressed in this review (OS and inflammation), Li et al. [133] and Shields et al. [134] described the typical change in microcirculation that occurs in diabetic patients after liver surgery. The ischaemic period and liver perfusion recovery are important factors related to hepatocellular damage because microcirculatory collapse is followed by a pronounced reduction of tissue oxygenation [135], which might result in degeneration and necrosis of hepatocytes and consequent liver dysfunction [136]. Experimental models of I/R injury have offered evidence that insufficient hepatic microcirculatory perfusion, inflammatory cell activation, and consequent generation of ROS, cytokines, and chemokines can be considered essential in I/R syndrome [137]. Although the authors [133, 134] did not report the relationship between diabetic liver failure after liver surgery and microcirculation collapse, we take this opportunity to raise this question for the development of future studies.

The alterations of hepatic haemodynamics are also related to hepatic steatosis, and a decrease in portal vein haemodynamics is observed in patients with a fatty liver disease $[138,139]$. Moreover, experimental animals with steatosis present decreased parenchymal microcirculation [140]. Hepatic steatosis has long been reported in type 1 [141] and type 2 DM [142]. Steatosis is common in diabetic patients (36\% incidence) [143], and increased steatosis raises the sensibility of the liver parenchyma to I/R injury [144]. In steatotic livers, the parenchymal regeneration ability is impaired, particularly after a surgical procedure [115], which may partially explain the incapacity of some diabetic patients to resist liver surgery. The high mortality observed in diabetic patients is absent in nondiabetic patients with steatosis [143]. In hepatocytes, increased accumulation of fatty acids induces OS arising from mitochondria, peroxisomes, or microsomes. ROS and lipid peroxidation products can influence KCs and stimulate NF- $\kappa \mathrm{B}$ activation, which in turn stimulates the production of TNF- $\alpha$ and several proinflammatory cytokines, such as IL-6 [143], which are presented in this review as factors involved in decreased regeneration and increased liver damage.

\section{Conclusion}

The purpose of this review was to discuss the literature addressing the damaging effect of DM on liver recovery after a surgical procedure and, especially, to highlight the need to expand knowledge of this issue to benefit patients with DM subjected to surgical procedures, which are increasing in clinical practice. Extensive work is still necessary to assess the differences between the diabetic and nondiabetic liver after a surgical procedure. Exploring this subject will enable the development of new treatments that will improve the success of diabetic liver recovery after surgery.

\section{Conflicts of Interest}

The authors declare that they have no conflicts of interest. The authors declare that there is no conflict of interest that would prejudice the impartiality of this scientific work.

\section{Acknowledgments}

The authors apologize to the many researchers whose work they have not been able to discuss in this limited review. The authors are supported by Grants 2016/24992-0 and 2017/11540-7 from the São Paulo Research Foundation (FAPESP), Grant 301617/2016-3 from the National Counsel of Technological and Scientific Development (CNPq, PQ1D), and the Coordenação de Aperfeiçoamento de Pessoal de Nível Superior (CAPES).

\section{References}

[1] D. J. Powner, "Factors during donor care that may affect liver transplantation outcome," Progress in Transplantation, vol. 14, no. 3, pp. 241-249, 2004.

[2] J. M. Henderson, "Liver transplantation and rejection: an overview," Hepato-Gastroenterology, vol. 46, Supplement 2, pp. 1482-1484, 1999.

[3] F. Serracino-Inglott, N. A. Habib, and R. T. Mathie, "Hepatic ischemia-reperfusion injury," The American Journal of Surgery, vol. 181, no. 2, pp. 160-166, 2001.

[4] S. Celik, S. Erdogan, and M. Tuzcu, "Caffeic acid phenethyl ester (CAPE) exhibits significant potential as an antidiabetic and liver-protective agent in streptozotocin-induced diabetic rats," Pharmacological Research, vol. 60, no. 4, pp. 270-276, 2009.

[5] M. Brownlee, "Biochemistry and molecular cell biology of diabetic complications," Nature, vol. 414, no. 6865, pp. 813820, 2001.

[6] A. Guven, O. Yavuz, M. Cam et al., "Effects of melatonin on streptozotocin-induced diabetic liver injury in rats," Acta Histochemica, vol. 108, no. 2, pp. 85-93, 2006.

[7] M. Romagnoli, M. C. Gomez-Cabrera, M. G. Perrelli et al., "Xanthine oxidase-induced oxidative stress causes activation of NF- $\kappa \mathrm{B}$ and inflammation in the liver of type I diabetic rats," Free Radical Biology \& Medicine, vol. 49, no. 2, pp. 171-177, 2010. 
[8] L. A. Videla, R. Rodrigo, M. Orellana et al., "Oxidative stressrelated parameters in the liver of non-alcoholic fatty liver disease patients," Clinical Science, vol. 106, no. 3, pp. 261-268, 2004.

[9] T. Fukuda, K. Ikejima, M. Hirose, Y. Takei, S. Watanabe, and N. Sato, "Taurine preserves gap junctional intercellular communication in rat hepatocytes under oxidative stress," Journal of Gastroenterology, vol. 35, no. 5, pp. 361-368, 2000.

[10] J. W. Baynes and S. R. Thorpe, "Role of oxidative stress in diabetic complications: a new perspective on an old paradigm," Diabetes, vol. 48, no. 1, pp. 1-9, 1999.

[11] J. W. Baynes, "Role of oxidative stress in development of complications in diabetes," Diabetes, vol. 40, no. 4, pp. 405412, 1991.

[12] K. C. Chang, S. Y. Chung, W. S. Chong et al., "Possible superoxide radical-induced alteration of vascular reactivity in aortas from streptozotocin-treated rats," The Journal of Pharmacology and Experimental Therapeutic, vol. 266, no. 2, pp. 992-1000, 1993.

[13] I. S. Young, S. Tate, J. H. Lightbody, D. McMaster, and E. R. Trimble, "The effects of desferrioxamine and ascorbate on oxidative stress in the streptozotocin diabetic rat," Free Radical Biology \& Medicine, vol. 18, no. 5, pp. 833-840, 1995.

[14] A. K. Saxena, P. Srivastava, R. K. Kale, and N. Z. Baquer, "Impaired antioxidant status in diabetic rat liver. Effect of vanadate," Biochemical Pharmacology, vol. 45, no. 3, pp. 539-542, 1993.

[15] S. V. McLennan, S. Heffernan, L. Wright et al., "Changes in hepatic glutathione metabolism in diabetes," Diabetes, vol. 40, no. 3, pp. 344-348, 1991.

[16] D. N. Granger and P. R. Kvietys, "Reperfusion injury and reactive oxygen species: the evolution of a concept," Redox Biology, vol. 6, pp. 524-551, 2015.

[17] W. Jassem, S. V. Fuggle, M. Rela, D. D. H. Koo, and N. D. Heaton, "The role of mitochondria in ischemia/reperfusion injury," Transplantation, vol. 73, no. 4, pp. 493-499, 2002.

[18] Q. Chen and B. N. Ames, "Senescence-like growth arrest induced by hydrogen peroxide in human diploid fibroblast F65 cells," Proceedings of the National Academy of Sciences of the United States of America, vol. 91, no. 10, pp. 41304134, 1994.

[19] D. A. Clopton and P. Saltman, "Low-level oxidative stress causes cell-cycle specific arrest in cultured cells," Biochemical and Biophysical Research Communications, vol. 210, no. 1, pp. 189-196, 1995.

[20] G. B. Corcoran, L. Fix, D. P. Jones et al., "Apoptosis: molecular control point in toxicity," Toxicology and Applied Pharmacology, vol. 128, no. 2, pp. 169-181, 1994.

[21] D. P. de Bono and W. D. Yang, "Exposure to low concentrations of hydrogen peroxide causes delayed endothelial cell death and inhibits proliferation of surviving cells," Atherosclerosis, vol. 114, no. 2, pp. 235-245, 1995.

[22] E. R. Whittemore, D. T. Loo, and C. W. Cotman, "Exposure to hydrogen peroxide induces cell death via apoptosis in cultured rat cortical neurons," Neuroreport, vol. 5, no. 12, pp. 1485-1488, 1994.

[23] V. N. Anisimov, "Ageing and the mechanisms of carcinogenesis: some practical implications," Journal of Experimental \& Clinical Cancer Research, vol. 17, no. 3, pp. 263-268, 1998.

[24] V. Sanchez-Valle, N. C. Chavez-Tapia, M. Uribe, and N. Mendez-Sanchez, "Role of oxidative stress and molecular changes in liver fibrosis: a review," Current Medicinal Chemistry, vol. 19, no. 28, pp. 4850-4860, 2012.

[25] E. Bugianesi, A. J. McCullough, and G. Marchesini, "Insulin resistance: a metabolic pathway to chronic liver disease," Hepatology, vol. 42, no. 5, pp. 987-1000, 2005.

[26] P. Manna, J. Das, J. Ghosh, and P. C. Sil, "Contribution of type 1 diabetes to rat liver dysfunction and cellular damage via activation of NOS, PARP, I $\kappa \mathrm{B} \alpha / \mathrm{NF}-\kappa \mathrm{B}$, MAPKs, and mitochondria-dependent pathways: prophylactic role of arjunolic acid," Free Radical Biology \& Medicine, vol. 48, no. 11, pp. 1465-1484, 2010.

[27] P. Palsamy, S. Sivakumar, and S. Subramanian, "Resveratrol attenuates hyperglycemia-mediated oxidative stress, proinflammatory cytokines and protects hepatocytes ultrastructure in streptozotocin-nicotinamide-induced experimental diabetic rats," Chemico-Biological Interactions, vol. 186, no. 2, pp. 200-210, 2010.

[28] Y. Zhang, D. Yuan, W. Yao et al., "Hyperglycemia aggravates hepatic ischemia reperfusion injury by inducing chronic oxidative stress and inflammation," Oxidative Medicine and Cellular Longevity, vol. 2016, Article ID 3919627, 16 pages, 2016.

[29] T. Şahin, Z. Begeç, H. İ. Toprak et al., "The effects of dexmedetomidine on liver ischemia-reperfusion injury in rats," Journal of Surgical Research, vol. 183, no. 1, pp. 385-390, 2013.

[30] S. Cem Sezen, B. Işık, M. Bilge et al., "Effect of dexmedetomidine on ischemia-reperfusion injury of liver and kidney tissues in experimental diabetes and hepatic ischemia-reperfusion injury induced rats," Anaesthesia, Pain \& Intensive Care, vol. 20, no. 2, pp. 143-149, 2016.

[31] H. Malhi, G. J. Gores, and J. J. Lemasters, "Apoptosis and necrosis in the liver: a tale of two deaths?," Hepatology, vol. 43, Supplement 1, pp. S31-S44, 2006.

[32] M. Behrends, G. Martinez-Palli, C. U. Niemann, S. Cohen, R. Ramachandran, and R. Hirose, "Acute hyperglycemia worsens hepatic ischemia/reperfusion injury in rats," Journal of Gastrointestinal Surgery, vol. 14, no. 3, pp. 528-535, 2010.

[33] H. Yamamoto, Y. Yamamoto, K. Yamagami et al., "Heatshock preconditioning reduces oxidative protein denaturation and ameliorates liver injury by carbon tetrachloride in rats," Research in Experimental Medicine, vol. 199, no. 6, pp. 309-318, 2000.

[34] M. E. Rinaldi Tosi, V. Bocanegra, W. Manucha, A. Gil Lorenzo, and P. G. Vallés, "The Nrf2-Keap1 cellular defense pathway and heat shock protein 70 (Hsp70) response. Role in protection against oxidative stress in early neonatal unilateral ureteral obstruction (UUO)," Cell Stress and Chaperones, vol. 16, no. 1, pp. 57-68, 2011.

[35] B. Halliwell and J. M. Gutteridge, "Lipid peroxidation, oxygen radicals, cell damage, and antioxidant therapy," The Lancet, vol. 1, no. 8391, pp. 1396-1397, 1984.

[36] G. K. Glantzounis, H. J. Salacinski, W. Yang, B. R. Davidson, and A. M. Seifalian, "The contemporary role of antioxidant therapy in attenuating liver ischemia-reperfusion injury: a review," Liver Transplantation, vol. 11, no. 9, pp. 10311047, 2005.

[37] K. Kudoh, H. Uchinami, M. Yoshioka, E. Seki, and Y. Yamamoto, "Nrf2 activation protects the liver from ischemia/reperfusion injury in mice," Annals of Surgery, vol. 260, no. 1, pp. 118-127, 2014. 
[38] M. Buelna-Chontal and C. Zazueta, "Redox activation of Nrf2 \& NF- $\kappa$ B: a double end sword?," Cellular Signalling, vol. 25, no. 12 , pp. 2548-2557, 2013.

[39] G. H. Liu, J. Qu, and X. Shen, "NF- $\kappa B / p 65$ antagonizes Nrf2ARE pathway by depriving CBP from Nrf2 and facilitating recruitment of HDAC3 to MafK," Biochimica et Biophysica Acta (BBA) - Molecular Cell Research, vol. 1783, no. 5, pp. 713-727, 2008.

[40] D. E. Francés, P. I. Ingaramo, M. T. Ronco, and C. E. Carnovale, "Diabetes, an inflammatory process: oxidative stress and TNF-alpha involved in hepatic complication," Journal of Biomedical Science and Engineering, vol. 6, no. 6, pp. 645-653, 2013.

[41] I. C. West, "Radicals and oxidative stress in diabetes," Diabetic Medicine, vol. 17, no. 3, pp. 171-180, 2000.

[42] J. W. Elrod, M. R. Duranski, W. Langston et al., "eNOS gene therapy exacerbates hepatic ischemia-reperfusion injury in diabetes: a role for eNOS uncoupling," Circulation Research, vol. 99, no. 1, pp. 78-85, 2006.

[43] P.-M. Sinet and P. Garber, "Inactivation of the human CuZn superoxide dismutase during exposure to $\mathrm{O}_{2}^{-}$and $\mathrm{H}_{2} \mathrm{O}_{2}$," Archives of Biochemistry and Biophysics, vol. 212, no. 2, pp. 411-416, 1981.

[44] Y. Kono and I. Fridovich, "Superoxide radical inhibits catalase," Journal of Biological Chemistry, vol. 257, no. 10, pp. 5751-5754, 1982.

[45] A. T. H. Mossa, A. A. Refaie, A. Ramadan, and J. Bouajila, "Amelioration of prallethrin-induced oxidative stress and hepatotoxicity in rat by the administration of Origanum majorana essential oil," BioMed Research International, vol. 2013, Article ID 859085, 11 pages, 2013.

[46] A. Choukér, A. Martignoni, R. J. Schauer et al., “ $\alpha$ Gluthathione S-transferase as an early marker of hepatic ischemia/reperfusion injury after liver resection," World Journal of Surgery, vol. 29, no. 4, pp. 528-534, 2005.

[47] C. E. Carnovale, J. A. Monti, C. Favre, C. Scapini, and M. C. Carrillo, "Is intestinal cytosolic glutathione S-transferase an alternative detoxification pathway in two-thirds hepatectomized rats?," Life Sciences, vol. 57, no. 9, pp. 903-910, 1995.

[48] M. T. Ronco, M. L. de Alvarez, J. Monti et al., "Modulation of balance between apoptosis and proliferation by lipid peroxidation (LPO) during rat liver regeneration," Molecular Medicine, vol. 8, no. 12, pp. 808-817, 2002.

[49] I. Aguilar-Delfín, F. López-Barrera, and R. HernándezMuñoz, "Selective enhancement of lipid peroxidation in plasma membrane in two experimental models of liver regeneration: partial hepatectomy and acute CC14 administration," Hepatology, vol. 24, no. 3, pp. 657-662, 1996.

[50] D. E. Francés, M. T. Ronco, P. I. Ingaramo et al., "Role of reactive oxygen species in the early stages of liver regeneration in streptozotocin-induced diabetic rats," Free Radical Research, vol. 45, no. 10, pp. 1143-1153, 2011.

[51] S. Chin, S. Ramirez, L. E. Greenbaum, A. Naji, and R. Taub, "Blunting of the immediate-early gene and mitogenic response in hepatectomized type 1 diabetic animals," American Journal of Physiology-Endocrinology and Metabolism, vol. 269, no. 4, pp. E691-E700, 1995.

[52] A. A. Aznar, C. T. Sanchez, M. L. B. Remacha, A. A. Lopez, and P. L. Diaz, "Effect of alloxan-induced diabetes on hepatic regeneration," Revista Española de Enfermedades Digestivas, vol. 79, pp. 313-319, 1991.
[53] P. W. Mola, B. Sudha, and C. S. Paulose, "Effect of insulin on DNA synthesis and kinetic parameters of thymidine kinase during liver regeneration," Biochemistry and Molecular Biology International, vol. 40, no. 5, pp. 1067-1075, 1996.

[54] S. S. Devi and H. M. Mehendale, "Disrupted G1 to S phase clearance via cyclin signaling impairs liver tissue repair in thioacetamide-treated type 1 diabetic rats," Toxicology and Applied Pharmacology, vol. 207, no. 2, pp. 89-102, 2005.

[55] D. E. Francés, M. T. Ronco, J. A. Monti et al., "Hyperglycemia induces apoptosis in rat liver through the increase of hydroxyl radical: new insights into the insulin effect," Journal of Endocrinology, vol. 205, no. 2, pp. 187-200, 2010.

[56] G. Andican and G. Burçak, "Oxidative damage to nuclear DNA in streptozotocin-diabetic rat liver," Clinical and Experimental Pharmacology and Physiology, vol. 32, no. 8, pp. 663-666, 2005.

[57] C. Brenner, L. Galluzzi, O. Kepp, and G. Kroemer, "Decoding cell death signals in liver inflammation," Journal of Hepatology, vol. 59, no. 3, pp. 583-594, 2013.

[58] J. Mohamed, A. H. Nazratun Nfizah, A. H. Zariyantey, and S. B. Budin, "Mechanisms of diabetes-induced liver damage: the role of oxidative stress and inflammation," Sultan Qaboos University Medical Journal, vol. 16, no. 2, pp. e132-e141, 2016.

[59] E. Faist, C. Schinkel, and S. Zimmer, "Update on the mechanisms of immune suppression of injury and immune modulation," World Journal of Surgery, vol. 20, no. 4, pp. 454-459, 1996.

[60] K. K. S. Sunahara, P. Sannomiya, and J. O. Martins, "Briefs on insulin and innate immune response," Cellular Physiology and Biochemistry, vol. 29, no. 1-2, pp. 1-8, 2012.

[61] S. C. Trevelin, D. Carlos, M. Beretta, J. S. da Silva, and F. Q. Cunha, "Diabetes mellitus and sepsis: a challenging association," Shock, vol. 47, no. 3, pp. 276-287, 2017.

[62] I. Gavrylenko and M. Khomenko, "Morphological and functional state of immune organs in rats with experimental type 1 diabetes mellitus (DM-1)," Journal of Medical and Dental Science Research, vol. 4, no. 1, pp. 6-10, 2017.

[63] F. Spiller, D. Carlos, F. O. Souto et al., " $\alpha 1$-Acid glycoprotein decreases neutrophil migration and increases susceptibility to sepsis in diabetic mice," Diabetes, vol. 61, no. 6, pp. 15841591, 2012.

[64] D. M. André, M. C. Calixto, C. Sollon et al., "High-fat dietinduced obesity impairs insulin signaling in lungs of allergen-challenged mice: improvement by resveratrol," Scientific Reports, vol. 7, no. 1, p. 17296, 2017.

[65] D. M. André, M. C. Calixto, C. Sollon et al., "Therapy with resveratrol attenuates obesity-associated allergic airway inflammation in mice," International Immunopharmacology, vol. 38, pp. 298-305, 2016.

[66] B. L. Diaz, M. F. Serra, A. C. Alves et al., "Alloxan diabetes reduces pleural mast cell numbers and the subsequent eosinophil influx induced by allergen in sensitized rats," International Archives of Allergy and Immunology, vol. 111, no. 1, pp. 36-43, 1996.

[67] S. C. Cavalher-Machado, W. T. de Lima, A. S. Damazo et al., "Down-regulation of mast cell activation and airway reactivity in diabetic rats: role of insulin," The European Respiratory Journal, vol. 24, no. 4, pp. 552-558, 2004.

[68] E. Boichot, P. Sannomiya, N. Escofier, N. Germain, Z. B. Fortes, and V. Lagente, "Endotoxin-induced acute lung injury 
in rats. Role of insulin," Pulmonary Pharmacology and Therapeutics, vol. 12, no. 5, pp. 285-290, 1999.

[69] J. Panés, I. Kurose, M. D. Rodriguez-Vaca et al., "Diabetes exacerbates inflammatory responses to ischemia-reperfusion," Circulation, vol. 93, no. 1, pp. 161-167, 1996.

[70] J. Parekh, C. U. Niemann, K. Dang, and R. Hirose, "Intraoperative hyperglycemia augments ischemia reperfusion injury in renal transplantation: a prospective study," Journal of Transplantation, vol. 2011, 7 pages, 2011.

[71] S. Yue, H. M. Zhou, J. J. Zhu et al., "Hyperglycemia and liver ischemia reperfusion injury: a role for the advanced glycation endproduct and its receptor pathway," American Journal of Transplantation, vol. 15, no. 11, pp. 2877-2887, 2015.

[72] H. Jaeschke, A. Farhood, and C. W. Smith, "Neutrophils contribute to ischemia/reperfusion injury in rat liver in vivo," FASEB Journal, vol. 4, no. 15, pp. 3355-3359, 1990.

[73] A. B. Lentsch, A. Kato, H. Yoshidome, K. M. McMasters, and M. J. Edwards, "Inflammatory mechanisms and therapeutic strategies for warm hepatic ischemia/reperfusion injury," Hepatology, vol. 32, no. 2, pp. 169-173, 2000.

[74] M. Shuh, H. Bohorquez, Loss GE Jr, and A. J. Cohen, "Tumor necrosis factor- $\alpha$ : life and death of hepatocytes during liver ischemia/reperfusion injury," The Ochsner Journal, vol. 13, no. 1, pp. 119-130, 2013.

[75] K. R. Karlmark, R. Weiskirchen, H. W. Zimmermann et al., "Hepatic recruitment of the inflammatory $\mathrm{Grl}^{+}$monocyte subset upon liver injury promotes hepatic fibrosis," Hepatology, vol. 50, no. 1, pp. 261-274, 2009.

[76] N. Hisama, Y. Yamaguchi, N. Miyanari et al., "Ischemiareperfusion injury: the role of Kupffer cells in the production of cytokine induced neutrophil chemoattractant, a member of the interleukin-8 family," Transplant Proceeding, vol. 27, no. 2, pp. 1604-1606, 1995.

[77] N. Hisama, Y. Yamaguchi, T. Ishiko et al., "Kupffer cell production of cytokine-induced neutrophil chemoattractant following ischemia/reperfusion injury in rats," Hepatology, vol. 24, no. 5, pp. 1193-1198, 1996.

[78] G. A. Wanner, P. E. Müller, W. Ertel, M. Bauer, M. D. Menger, and K. Messmer, "Differential effect of antiTNF-alpha antibody on proinflammatory cytokine release by Kupffer cells following liver ischemia and reperfusion," Shock, vol. 11, no. 6, pp. 391-395, 1999.

[79] A. Nakamitsu, E. Hiyama, Y. Imamura, Y. Matsuura, and T. Yokoyama, "Kupffer cell function in ischemic and nonischemic livers after hepatic partial ischemia/reperfusion," Surgery Today, vol. 31, no. 2, pp. 140-148, 2001.

[80] B. Mosher, R. Dean, J. Harkema, D. Remick, J. Palma, and E. Crockett, "Inhibition of Kupffer cells reduced CXC chemokine production and liver injury," Journal of Surgical Research, vol. 99, no. 2, pp. 201-210, 2001.

[81] Z. Rao, J. Sun, X. Pan et al., "Hyperglycemia aggravates hepatic ischemia and reperfusion injury by inhibiting liverresident macrophage $\mathrm{M} 2$ polarization via $\mathrm{C} / \mathrm{EBP}$ homologous protein-mediated endoplasmic reticulum stress," Frontiers in Immunology, vol. 8, pp. 1-10, 2017.

[82] Y. T. Zhao, Y. W. Qi, C. Y. Hu, S. H. Chen, and Y. Liu, "Advanced glycation end products inhibit testosterone secretion by rat Leydig cells by inducing oxidative stress and endoplasmic reticulum stress," International Journal of Molecular Medicine, vol. 38, no. 2, pp. 659-665, 2016.
[83] C. Adamopoulos, E. Farmaki, E. Spilioti, H. Kiaris, C. Piperi, and A. G. Papavassiliou, "Advanced glycation end-products induce endoplasmic reticulum stress in human aortic endothelial cells," Clinical Chemistry and Laboratory Medicine, vol. 52, no. 1, pp. 151-160, 2014.

[84] J. Xu, M. Xiong, B. Huang, and H. Chen, “Advanced glycation end products upregulate the endoplasmic reticulum stress in human periodontal ligament cells," Journal of Periodontology, vol. 86, no. 3, pp. 440-447, 2015.

[85] S. Yamabe, J. Hirose, Y. Uehara et al., "Intracellular accumulation of advanced glycation end products induces apoptosis via endoplasmic reticulum stress in chondrocytes," FEBS Journal, vol. 280, no. 7, pp. 1617-1629, 2013.

[86] T. Lawrence and G. Natoli, "Transcriptional regulation of macrophage polarization: enabling diversity with identity," Nature Reviews Immunology, vol. 11, no. 11, pp. 750-761, 2011.

[87] S. Yue, J. Rao, J. Zhu et al., "Myeloid PTEN deficiency protects livers from ischemia reperfusion injury by facilitating M2 macrophage differentiation," The Journal of Immunology, vol. 192, no. 11, pp. 5343-5353, 2014.

[88] S. Müller, S. Martin, W. Koenig et al., "Impaired glucose tolerance is associated with increased serum concentrations of interleukin 6 and co-regulated acute-phase proteins but not TNF-alpha or its receptors," Diabetologia, vol. 45 , no. 6 , pp. 805-812, 2002.

[89] M. Crook, "Type 2 diabetes mellitus: a disease of the innate immune system? An update," Diabetic Medicine, vol. 21, no. 3, pp. 203-207, 2004.

[90] K. I. Alexandraki, C. Piperi, P. D. Ziakas et al., "Cytokine secretion in long-standing diabetes mellitus type 1 and 2: associations with low-grade systemic inflammation," Journal of Clinical Immunology, vol. 28, no. 4, pp. 314-321, 2008.

[91] G. Boden, P. She, M. Mozzoli et al., "Free fatty acids produce insulin resistance and activate the proinflammatory nuclear factor- $\kappa \mathrm{B}$ pathway in rat liver," Diabetes, vol. 54 , no. 12 , pp. 3458-3465, 2005.

[92] Y. Iwasaki, M. Kambayashi, M. Asai, M. Yoshida, T. Nigawara, and K. Hashimoto, "High glucose alone, as well as in combination with proinflammatory cytokines, stimulates nuclear factor kappa-B-mediated transcription in hepatocytes in vitro," Journal of Diabetes and its Complications, vol. 21, no. 1, pp. 56-62, 2007.

[93] Y. Bi, W. P. Sun, X. Chen et al., "Effect of early insulin therapy on nuclear factor $\kappa \mathrm{B}$ and cytokine gene expressions in the liver and skeletal muscle of high-fat diet, streptozotocintreated diabetic rats," Acta Diabetologica, vol. 45, no. 3, pp. 167-178, 2008.

[94] U. Siebenlist, G. Franzoso, and K. Brown, "Structure, regulation and function of NF- $\kappa \mathrm{B}$," Annual Review of Cell Biology, vol. 10, no. 1, pp. 405-455, 1994.

[95] M. J. Morgan and Z. G. Liu, "Crosstalk of reactive oxygen species and NF- $\kappa \mathrm{B}$ signaling," Cell Research, vol. 21, no. 1, pp. 103-115, 2011.

[96] M. Niwa, A. Hara, Y. Kanamori et al., "Nuclear factor- $\kappa$ B activates dual inhibition sites in the regulation of tumor necrosis factor- $\alpha$-induced neutrophil apoptosis," European Journal of Pharmacology, vol. 407, no. 3, pp. 211-219, 2000. 
[97] R. F. Saidi and S. K. H. Kenari, "Liver ischemia/reperfusion injury: an overview," Journal of Investigative Surgery, vol. 27, no. 6, pp. 366-379, 2014.

[98] A. R. Brasier and J. Li, "Mechanisms for inducible control of angiotensinogen gene transcription," Hypertension, vol. 27, no. 3, pp. 465-475, 1996.

[99] J. Li and A. R. Brasier, "Angiotensinogen gene activation by angiotensin II is mediated by the rel A (nuclear factorkappaB p65) transcription factor: one mechanism for the renin angiotensin system positive feedback loop in hepatocytes," Molecular Endocrinology, vol. 10, no. 3, pp. 252-264, 1996.

[100] P. I. Ingaramo, M. T. Ronco, D. E. A. Francés et al., “Tumor necrosis factor alpha pathways develops liver apoptosis in type 1 diabetes mellitus," Molecular Immunology, vol. 48, no. 12-13, pp. 1397-1407, 2011.

[101] P. Dandona, A. Chaudhuri, H. Ghanim, and P. Mohanty, "Proinflammatory effects of glucose and antiinflammatory effect of insulin: relevance to cardiovascular disease," American Journal of Cardiology, vol. 99, no. 4A, pp. 15B-26B, 2007.

[102] F. M. Ho, W. W. Lin, B. C. Chen et al., "High glucose-induced apoptosis in human vascular endothelial cells is mediated through NF- $\kappa \mathrm{B}$ and $c$-Jun NH2-terminal kinase pathway and prevented by PI3K/Akt/eNOS pathway," Cellular Signalling, vol. 18, no. 3, pp. 391-399, 2006.

[103] Y. Ito, H. Katagiri, K. Ishii, A. Kakita, I. Hayashi, and M. Majima, "Effects of selective cyclooxygenase inhibitors on ischemia/reperfusion-induced hepatic microcirculatory dysfunction in mice," European Surgical Research, vol. 35, no. 5, pp. 408-416, 2003.

[104] Y. Sunose, I. Takeyoshi, S. Ohwada et al., "The effect of cyclooxygenase-2 inhibitor FK3311 on ischemia-reperfusion injury in a canine total hepatic vascular exclusion model," Journal of the American College of Surgeons, vol. 192, no. 1, pp. 54-62, 2001.

[105] I. Takeyoshi, Y. Sunose, S. Iwazaki et al., "The effect of a selective cyclooxygenase-2 inhibitor in extended liver resection with ischemia in dogs," Journal of Surgical Research, vol. 100, no. 1, pp. 25-31, 2001.

[106] A. Wullaert, K. Heyninck, and R. Beyaert, "Mechanisms of crosstalk between TNF-induced NF- $\kappa$ B and JNK activation in hepatocytes," Biochemical Pharmacology, vol. 72, no. 9, pp. 1090-1101, 2006.

[107] D. E. A. Francés, P. I. Ingaramo, R. Mayoral et al., "Cyclooxygenase-2 over-expression inhibits liver apoptosis induced by hyperglycemia," Journal of Cellular Biochemistry, vol. 114, no. 3, pp. 669-680, 2013.

[108] M. Torbenson, S. Q. Yang, H. Z. Liu, J. Huang, W. Gage, and A. M. Diehl, "STAT-3 overexpression and p21 up-regulation accompany impaired regeneration of fatty livers," American Journal of Pathology, vol. 161, no. 1, pp. 155-161, 2002.

[109] T. Matsumoto, M. Yamaguchi, M. Kuzume et al., "Insulin gene transfer improves posthepatectomized status of diabetic rats," Transplantation Proceedings, vol. 32, no. 7, pp. 23782379, 2000.

[110] K. Shirabe, M. Shimada, T. Gion et al., "Postoperative liver failure after major hepatic resection for hepatocellular carcinoma in the modern era with special reference to remnant liver volume," Journal of American College of Surgeons, vol. 188, no. 3, pp. 304-309, 1999.
[111] T. Aoyama, K. Ikejima, K. Kon, K. Okumura, K. Arai, and S. Watanabe, "Pioglitazone promotes survival and prevents hepatic regeneration failure after partial hepatectomy in obese and diabetic KK-Ay mice," Hepatology, vol. 49, no. 5, pp. 1636-1644, 2009.

[112] P. Akerman, P. Cote, S. Q. Yang et al., "Antibodies to tumor necrosis factor-alpha inhibit liver regeneration after partial hepatectomy," American Journal of PhysiologyGastrointestinal and Liver Physiology, vol. 263, no. 4, pp. G579-G585, 1992.

[113] A. M. Diehl, S. Q. Yang, M. Yin, H. Z. Lin, S. Nelson, and G. Bagby, "Tumor necrosis factor-alpha modulates CCAA T/enhancer binding proteins-DNA binding activities and promotes hepatocyte-specific gene expression during liver regeneration," Hepatology, vol. 22, no. 1, pp. 252-261, 1995.

[114] S. Nepal and P. H. Park, "Modulation of cell death and survival by adipokines in the liver," Biological and Pharmaceutical Bulletin, vol. 38, no. 7, pp. 961-965, 2015.

[115] M. Mendes-Braz, M. Elias-Miró, B. Kleuser et al., “The effects of glucose and lipids in steatotic and non-steatotic livers in conditions of partial hepatectomy under ischaemia-reperfusion," Liver International, vol. 34, no. 7, pp. e271-e289, 2014.

[116] T. Masaki, S. Chiba, H. Tatsukawa et al., "Adiponectin protects LPS-induced liver injury through modulation of TNF- $\alpha$ in KK-Ay obese mice," Hepatology, vol. 40, no. 1, pp. 177-184, 2004.

[117] H. Matsumoto, S. Tamura, Y. Kamada et al., "Adiponectin deficiency exacerbates lipopolysaccharide/D-galactosamine induced liver injury in mice," World Journal of Gastroenterology, vol. 12, no. 21, pp. 3352-3358, 2006.

[118] M. B. Jiménez-Castro, A. Casillas-Ramírez, M. Mendes-Braz et al., "Adiponectin and resistin protect steatotic livers undergoing transplantation," Journal of Hepatology, vol. 59, no. 6, pp. 1208-1214, 2013.

[119] M. Massip-Salcedo, M. A. Zaouali, S. Padrissa-Altés et al., "Activation of peroxisome proliferator-activated receptor- $\alpha$ inhibits the injurious effects of adiponectin in rat steatotic liver undergoing ischemia-reperfusion," Hepatology, vol. 47, no. 2, pp. 461-472, 2008.

[120] K. Man, Y. Zhao, A. Xu et al., "Fat-derived hormone adiponectin combined with FTY720 significantly improves small-for-size fatty liver graft survival," American Journal of Transplantation, vol. 6, no. 3, pp. 467-476, 2006.

[121] D. Schmidt-Arras and S. Rose-John, "IL-6 pathway in the liver: from physiopathology to therapy," Journal of Hepatology, vol. 64, no. 6, pp. 1403-1415, 2016.

[122] R. Taub, "Liver regeneration: from myth to mechanism," Nature Reviews Molecular Cell Biology, vol. 5, no. 10, pp. 836-847, 2004.

[123] N. Fausto, J. S. Campbell, and K. J. Riehle, "Liver regeneration,” Hepatology, vol. 43, Supplement 1, pp. S45-S53, 2006.

[124] N. Ouchi, J. L. Parker, J. J. Lugus, and K. Walsh, “Adipokines in inflammation and metabolic disease," Nature Reviews Immunology, vol. 11, no. 2, pp. 85-97, 2011.

[125] S. Loffreda, S. Q. Yang, H. Z. Lin et al., "Leptin regulates proinflammatory immune responses," FASEB Journal, vol. 12, no. 1, pp. 57-65, 1998.

[126] G. Fantuzzi and R. Faggioni, "Leptin in the regulation of immunity, inflammation, and hematopoiesis," Journal of Leukocyte Biology, vol. 68, no. 4, pp. 437-446, 2000. 
[127] K. L. Streetz, F. Tacke, L. Leifeld et al., "Interleukin 6/ gp130-dependent pathways are protective during chronic liver diseases," Hepatology, vol. 38, no. 1, pp. 218-229, 2003.

[128] C. Klein, T. Wüstefeld, U. Assmus et al., “The IL-6-gp130STAT3 pathway in hepatocytes triggers liver protection in $\mathrm{T}$ cell-mediated liver injury," The Journal of Clinical Investigation, vol. 115, no. 4, pp. 860-869, 2005.

[129] D. E. Cressman, L. E. Greenbaum, R. A. DeAngelis et al., "Liver failure and defective hepatocyte regeneration in interleukin-6-deficient mice," Science, vol. 274, no. 5291, pp. 1379-1383, 1996.

[130] K. Streetz, T. Luedde, M. Manns, and C. Trautwein, "Interleukin 6 and liver regeneration," Gut, vol. 47, no. 2, pp. 309-312, 2000.

[131] T. Wüstefeld, T. Rakemann, S. Kubicka, M. P. Manns, and C. Trautwein, "Hyperstimulation with interleukin 6 inhibits cell cycle progression after hepatectomy in mice," Hepatology, vol. 32, no. 3, pp. 514-522, 2000.

[132] I. A. Leclercq, J. Field, and G. C. Farrell, "Leptin-specific mechanisms for impaired liver regeneration in ob/ob mice after toxic injury," Gastroenterology, vol. 124, no. 5, pp. 1451-1464, 2003.

[133] Q. Li, Y. Wang, T. Ma, Y. Lv, and R. Wu, "Clinical outcomes of patients with and without diabetes mellitus after hepatectomy: a systematic review and meta-analysis," PLoS One, vol. 12, no. 2, article e0171129, 2017.

[134] P. L. Shields, H. Tang, J. M. Neuberger, B. K. Gunson, P. McMaster, and J. Pirenne, "Poor outcome in patients with diabetes mellitus undergoing liver transplantation," Transplantation, vol. 68, no. 4, pp. 530-535, 1999.

[135] B. Vollmar, S. Richter, and M. D. Menger, "Liver ischemia/ reperfusion induces an increase of microvascular leukocyte flux, but not heterogeneity of leukocyte trafficking," Liver, vol. 17, no. 2, pp. 93-98, 1997.

[136] Y. Wan, J. Garner, N. Wu et al., "Role of stem cells during diabetic liver injury," Journal of Cellular and Molecular Medicine, vol. 20, no. 2, pp. 195-203, 2016.

[137] H. Jaeschke, "Molecular mechanisms of hepatic ischemiareperfusion injury and preconditioning," American Journal of Physiology, Gastrointestinal and Liver Physiology, vol. 284, no. 1, pp. G15-G26, 2003.

[138] A. Balci, S. Karazincir, H. Sumbas, Y. Oter, E. Egilmez, and T. Inandi, "Effects of diffuse fatty infiltration of the liver on portal vein flow hemodynamics," Journal of Clinical Ultrasound, vol. 36, no. 3, pp. 134-140, 2008.

[139] B. Erdogmus, A. Tamer, R. Buyukkaya et al., "Portal vein hemodynamics in patients with non-alcoholic fatty liver disease," Tohoku Journal of Experimental Medicine, vol. 215, no. 1, pp. 89-93, 2008.

[140] A. M. Seifalian, C. Piasecki, A. Agarwal, and B. R. Davidson, "The effect of graded steatosis on flow in the hepatic parenchymal microcirculation," Transplantation, vol. 68, no. 6, pp. 780-784, 1999.

[141] S. E. Regnell and Å. Lernmark, "Hepatic steatosis in type 1 diabetes," The Review of Diabetic Studies, vol. 8, no. 4, pp. 454-467, 2011.

[142] K. G. Tolman, V. Fonseca, A. Dalpiaz, and M. H. Tan, "Spectrum of liver disease in type 2 diabetes and management of patients with diabetes and liver disease," Diabetes Care, vol. 30, no. 3, pp. 734-743, 2007.
[143] S. A. Little, W. R. Jarnagin, R. P. DeMatteo, L. H. Blumgart, and Y. Fong, "Diabetes is associated with increased perioperative mortality but equivalent long-term outcome after hepatic resection for colorectal cancer," Journal of Gastrointestinal Surgery, vol. 6, no. 1, pp. 88-94, 2002.

[144] M. Selzner, H. Rüdiger, D. Sindram, J. Madden, and P. Clavien, "Mechanisms of ischemic injury are different in the steatotic and normal rat liver," Hepatology, vol. 32, no. 6 , pp. 1280-1288, 2000. 


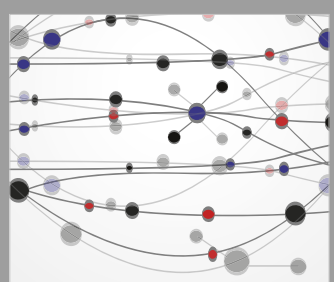

The Scientific World Journal
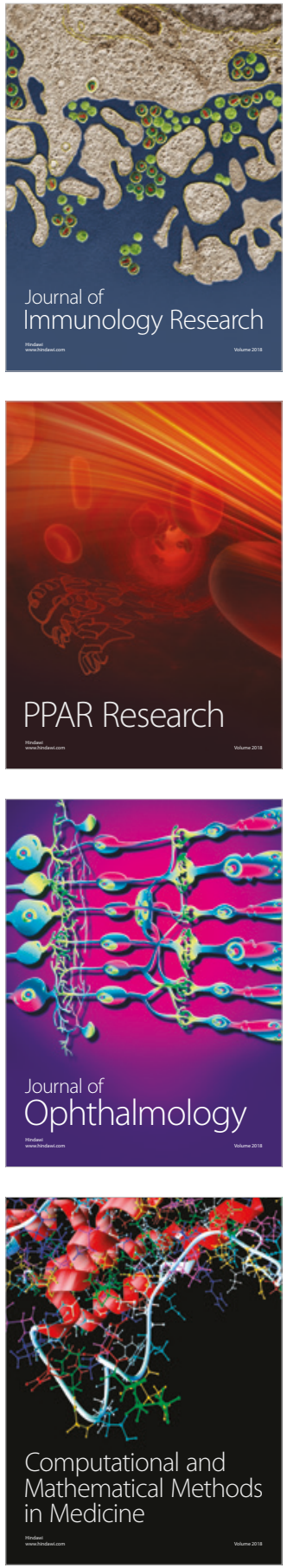

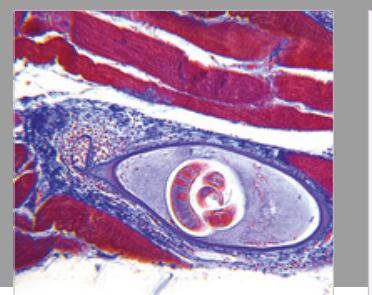

Gastroenterology Research and Practice

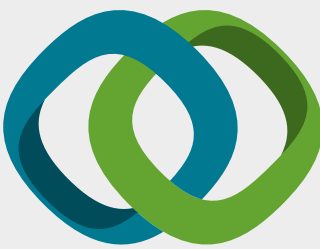

\section{Hindawi}

Submit your manuscripts at

www.hindawi.com
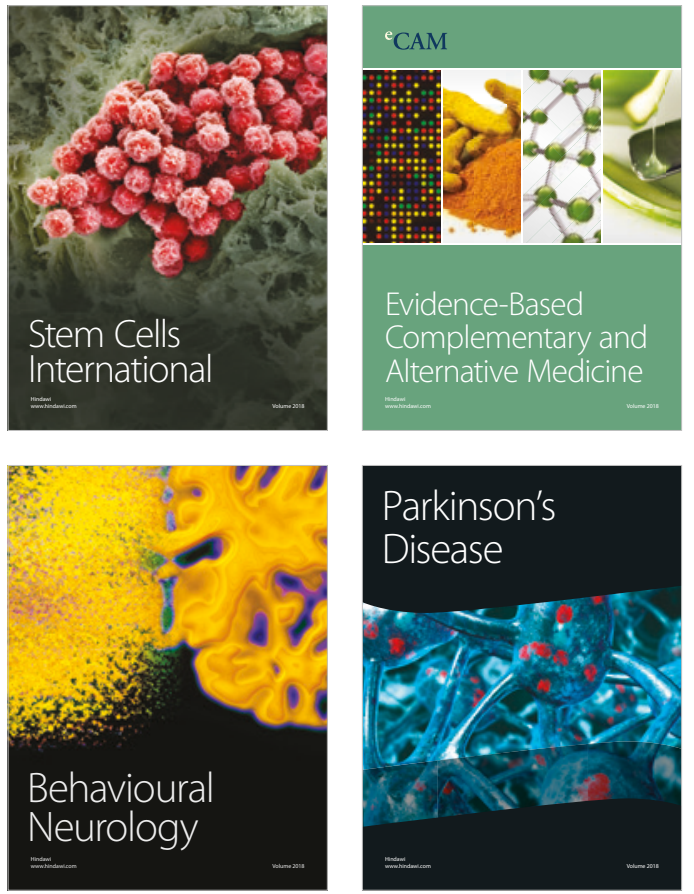

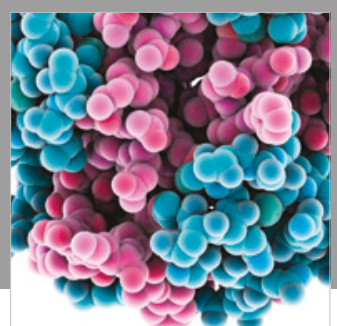

ournal of

Diabetes Research

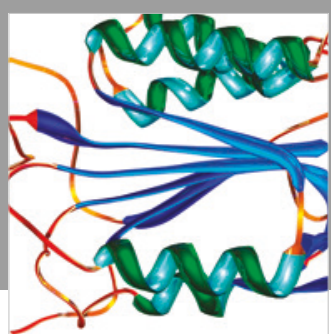

Disease Markers
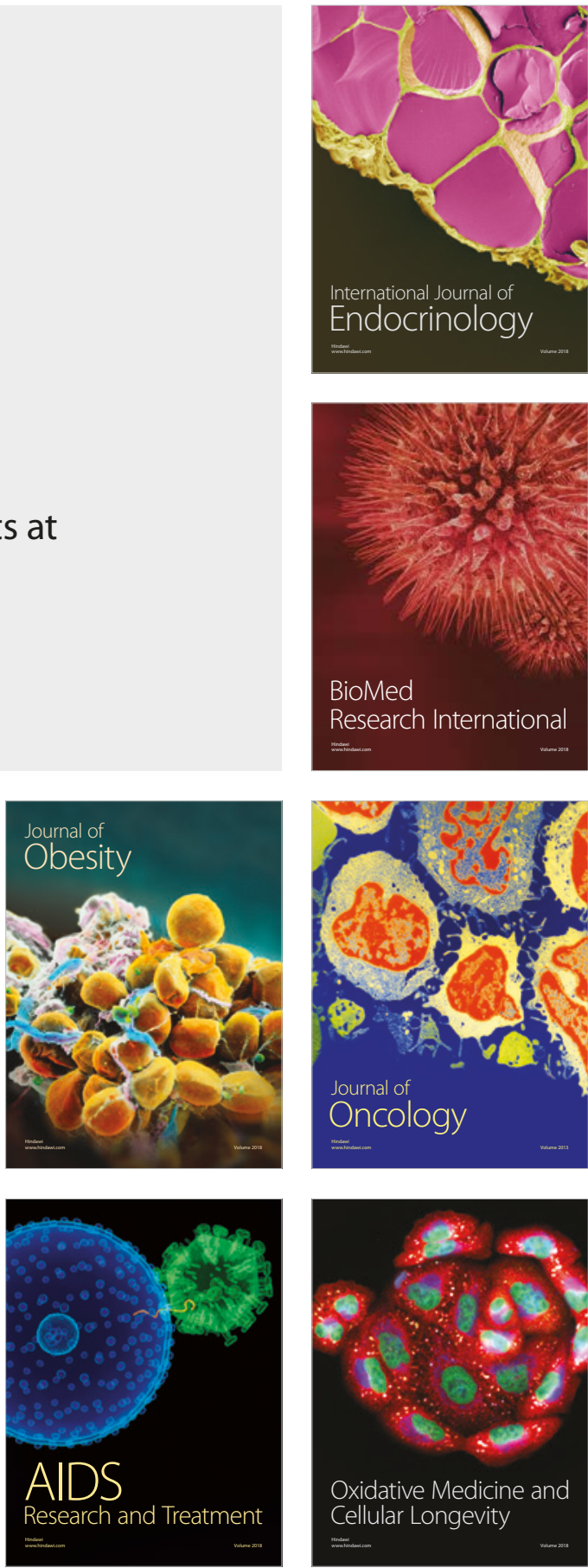